\title{
Research on The Present Situation and Development Trend of 020
}

\section{Model}

\section{Shu-cui Shi}

\author{
Qingdao Huanghai University, Qingdao, Shandong, China
}

\begin{abstract}
With the rapid development of E-commerce ,more and more enterprises and consumers are paying close contention to $\mathrm{O} 2 \mathrm{O}$ marketing model, and the effective integration of online and offline marketings is the direction for $\mathrm{O} 2 \mathrm{O}$ development. In this paper, policy, economy, society and technology factors were studied, then makes a general analysis of O2O's present situation and development trend.
\end{abstract}

Keywords: O2O, Mobile e-commerce, E-commerce

\section{Introduction}

With the rapid development of e-commerce, $\mathrm{O} 2 \mathrm{O}$ is attracting more and more attention from enterprises and consumers. O2O originally refers to online to offline or offline to online, broadly speaking, in the industrial chain, all the models involved in online offline can be called O2O, narrowly $\mathrm{O} 2 \mathrm{O}$ emphasizes that consumers buy and pay/subscribe to a certain kind of service or merchandise through the online platform, and to complete the transaction after the experience or consumption of the offline store. At present, catering and the leisure entertainment are integrating better with the industry. The business logic of $\mathrm{O} 2 \mathrm{O}$ mode refers to the user online platform browse payment and offline consumer experience. The merchant can track its marketing effect in real time, thus forming the closed loop business service and experience process.

$\mathrm{O} 2 \mathrm{O}$ industry weighs significantly, in the retail and local life service. The industry performance is particularly evident, group-buying website can be considered as the early $\mathrm{O} 2 \mathrm{O}$ model, mainly involved in merchants, users and online platform. At present, there are roughly four types of comprehensive $\mathrm{O} 2 \mathrm{O}$ model : (1) online offline: online payment, offline consumption experience. such as Ctrip , Volkswagen reviews (2) offline to online: offline marketing to the line to complete the transaction, for example, online education and online doctors (3) online offline to online: Online marketing to the offline experience to line transactions, such as Home and other industries (4) offline on-line to off-line: offline marketing to online trading experience.

\section{The development of the $\mathrm{O} 2 \mathrm{O}$ environment}

The policy environment

The two sessions of the Government's work report pointed out that with the Internet as the carrier, online offline interactive new consumption is booming. In September 2015, the State Council issued the " about promoting online interaction to speed up the transformation and upgrading of commerce and trade circulation innovation and development of opinion ", which is the country's first policy that mentioned $\mathrm{O} 2 \mathrm{O}$, promoting digital reform, increasing the fiscal and financial support. The policy encourages retail enterprises to change mode of operation, reversing the sales to the development of "goods and services" for consumers to experience. 
The economic environment

Economic development needs a new model, and $\mathrm{O} 2 \mathrm{O}$ provides a reference to the transformation of the channel for reference. Online and offline integration become industry investment hot spots and development direction. $\mathrm{O} 2 \mathrm{O}$ emergence and continuous innovation provide a new development environment for enterprises. Since 2012, the rapid development of online electric merchants has made enterprises transform and upgrade,and they urgently need to find new breakthrough to adapt to the new economic environment.

The social environment

As of December 2016, there are 731 million Internet users in China, the penetration rate reached $53.2 \%$, which is more than the global average of $3.1 \%$, more than the Asian average of $7.6 \%$.A total of 42.99 million Internet users are newly emerged users, the growth rate of $6.2 \%$. There are 695 million mobile Internet users in China, the growth rate of over $10 \%$ for three consecutive years. User of desktop computers, notebook computers all fell,but the users of mobile phone constantly increase. Consumers' dependence on mobile devices such as mobile phones is stronger, users have formed the habit of using cell phones and applications, and the development of the $\mathrm{O} 2 \mathrm{O}$ online environment has been developed.

The technology environment

Technical environment for the development of $\mathrm{O} 2 \mathrm{O}$ matures, large data, cloud computing and DSP, LBA positioning technology, mobile payment, mobile customer services and etc. All these help consumers more convenient, with a stronger psychological experience. Benefits driven the innovation of technology development, in the mobile payment of the emergence of Alipay, Baidu Purse,micro-letter wallet transfers such as payment means, which is also a common way of daily life people pay. The combination of $\mathrm{O} 2 \mathrm{O}$ and mobile Internet will bring people unprecedented innovation, $\mathrm{O} 2 \mathrm{O}$ enterprises appear to have the phenomenon of heating.

\section{$\mathrm{O} 2 \mathrm{O}$ and industry development present situation}

According to Eric's data, China's e-commerce market 2015 deals with a 16.4 trillion increase of 22.7\%. Among them, network shopping 36.2\% becomes the important power to promote the development of the electric market. Online travel grew by $39.9 \%$, local life service $\mathrm{O} 2 \mathrm{O}$ increased by 38.3\%. 2015 Mobile-end NET purchase market transaction size reached 2.1 trillion, annual growth rate of $123.8 \%$. The rapid development of online retailing continues to penetrate into the line. Ali,Beijing East,Suning and other electric business enterprises have embarked on the whole channel development.Beginning in 2012, Suning began to implement online the same price.

The scale of e-commerce market grows steadily, laying the foundation for the further fusion development of $\mathrm{O} 20$

2015 Mobile User scale reaches 380 million people, in which the net purchase users accounted for $92.4 \%$, the mobile end popularization development to carry on the various forms line on-line under the combination laid the foundation.

\section{Online and offline channels on complementary advantages, realize the sharing of information and data}

Internet companies such as 2015 BAT expand offline merchants, O2O layout retail and service areas. Ali,Suning and Jingdong focus on retailing electricity enterprises, such as Tencent, Baidu focuses on service. Online platform with large flow, goods complete kinds, recommended precision marketing and interactive strong advantages. Entity shop Yintai, Suning has strategic cooperation with Alibaba, Wanda also teamed up with Tencent,Baidu and Suning online. Regional Qingdao 
Liqun, a few years ago physical stores has also set up their own logistics company synchronous online mall and supermarket goods sales entity and has its tissue distribution logistics company.

\section{Local life service $\mathrm{O} 2 \mathrm{O}$ development is rapid, continue to infiltrate into all walks of life}

There are all walks of life to meet the diverse needs of users, and there has been a new $\mathrm{O} 2 \mathrm{O}$ development model: Online education, domestic services, legal advice, insurance industry also participated in it. Combining a taxi car rental service online, 2009 Are you hungry? Online, become well-known sites; In 2013 domestic O2O, Ejie and Aunt came online; Internet companies such as BAT into the O2O field in 2014;Didi a taxi-hikong App,in 2015 merged with Kuaidi, in 2016 Didi acquisited Uber. All the competition established on a deep mass base.

\section{Enterprises blindly develop low-frequency demand, financing difficulties}

The competition between E-commerce giants is getting harsh, which makes small enterprise difficult to survive. Strong capital backing is the foundation of the enterprise competition. Corporate financing is easy in the first stages financing is relatively simple. However, if there is no clear direction, blind development cannot bring huge profits to investors and only make capital chain rupture, causing the enterprise bankruptcy.

Homogeneity being serious, profit pattern being not clear caused a batch of enterprises eliminated

Part of the industry's spending habits have not been established,featuring low frequency and unsustainable. Large numbers of enterprises emerged in the past two years, countless enterprises fail again. A lot of wedding, home, travel, food and beverage industries are trying the new model of O2O.Serious homogeneity, no clear profit model, confusion of business model innovation, low demands all leads to serious loss and many enterprises bankruptcy, causing the waste of resources.

\section{Research on the future development trend of $\mathbf{O} 20$}

\section{Online and offline integration become the new development direction}

In 2015 the state council on promoting action guidance for "Internet + " under the guidance of some traditional enterprises began to use the Internet to think through the optimization of benefit distribution mechanism, trying to realize online fusion gradually. For enterprises can promote the development trend of the integration of online buyers purchasing and supplier sales efficiency and success rate; Subvert the traditional sales mode to pay more attention to consumers as the center; Pay attention to consumer's shopping experience; A more emphasis on $\mathrm{O} 2 \mathrm{O}$ product online flow interaction, from the trend of the flow to the user of the dealer flow into; Online platform for the cooperation with offline businesses expand the category more goods and services to attract consumer's attention. Online interaction at the same time solves the problem of the stock inventory backlog, can help to improve traditional industry efficiency to reduce costs, improve service quality. Online and offline integration of all retail is the best business model, become the strategic choice for many companies.

The development of mobile e-commerce, make future $\mathrm{O} 2 \mathrm{O}$ service less affected by time and space constraints

The rapid development of mobile e-commerce, makes the regional scene in life gradually formed, the future $\mathrm{O} 2 \mathrm{O}$ makes consumers bound by time, space, less and less. According to statistics, the number of mobile users, mobile APP development and use is very common.

Big data applications, online data exchange of information sharing

Big data application and sharing are helpful for precision marketing online and offline enterprise, and effective delivery of goods and services. Use all kinds of Internet of things terminal including warehousing logistics system effective collection and analysis of user data, using data mining to 
convert the user data as data resources, strategy and marketing bring important reference for the enterprise. Use digital marketing to achieve the maximization of the user experience. Through online data exchange data $\mathrm{O} 2 \mathrm{O}$ closed loop, achieve the goal of precipitation users and is the key point of the next big data technology development.

\section{Local life service 020 presents differentiated development and builds their core competence through technological innovation}

Specialized level and service quality is the core competitiveness of the local life service O2O market, with the constant innovation of $\mathrm{O} 2 \mathrm{O}$ model development, this way of consumption brings the convenience to the user's colleague also gradually accepted by people. Developing rapidly in the first-tier cities $\mathrm{O} 2 \mathrm{O}$ consumption experienced the change from quantity to quality, consumers pay more attention to their own consumption experience and quality. As the user needs to deepen, O2O mode to infiltrate the renting, housekeeping, automobile, medical, education and other niche. Location-based $\backslash$ real-time, interactive, detailed ways emerged. Enterprises pay more attention in the process of continuous innovation of the quality of the goods and services provided. We can improve their core competitiveness from the following several aspects : (1) to improve service quality (2) meet the customers' requirements (3) the $\mathrm{O} 2 \mathrm{O}$ platform of information transparency (4) increase user stickiness.

\section{References}

[1] J. van der Geer, J.A.J. Hanraads, R.A. Lupton, The art of writing a scientific article, J. Sci. Commun. 163 (2000) 51-59.

[2] W. Strunk Jr., E.B. White, The Elements of Style, third ed., Macmillan, New York, 1979.

Reference to a chapter in an edited book: 